\title{
Surrey W. L. Jacobs (1946-2009) and aquatic plant research in Australia
}

\author{
Donald H. Les \\ University of Connecticut, Department of Ecology \& Evolutionary Biology, Storrs, \\ CT 06269-3043, USA \\ Email:les@uconn.edu
}

\begin{abstract}
This paper reviews and summarises the important contributions made to the study of aquatic angiosperms by the Australian botanist Surrey W. L. Jacobs, based largely on the personal experiences of the author. His field-oriented research resulted in the publication of more than 75 technical books and papers on aquatic and wetland plants, 38 newly named aquatic plant taxa, and a legacy of important botanical specimens collected from many remote localities. His field assistance and willing collaborative spirit also substantially enhanced the productivity of a significant number of professional colleagues and students who conducted research on aquatic plants.
\end{abstract}

\section{Introduction}

Surrey Jacobs' very first paper was a co-authored manuscript on 'dry-land vegetation' (Anderson et al. 1967). Several years later, he went on to complete a Ph.D. on the systematics and ecology of Triodia, a genus of spinifex grasses that dominates the arid Australian grasslands (Jacobs 1974). Several papers on Chenopodiaceae and arid zone plants soon followed (Carolin et al. 1975, 1978; Chapman \& Jacobs 1980). Given this initial research emphasis, one cannot help but wonder how a botanist with such a desiccated focus auspiciously began to devote a substantial segment of his time to the study of waterplants. Although one typically does not equate an advanced degree in grass ecology and keen interest in chenopods with the study of aquatic vegetation, those acquainted with Surrey Jacobs would recognise immediately that such a career course was far from atypical for a person whose research program embraced constant challenges.

I asked Surrey once why he chose to study waterplants. He firmly corrected me, confiding that he did not choose that avocation, but was 'strongly encouraged' to do so by his superiors, who recognised a need to clarify numerous taxonomic problems involving these troublesome plants. At first he saw the task as highly onerous, only to eventually devote a good portion of his life fulfilling it, and ultimately to emerge 
as a foremost specialist in the taxonomy of aquatic Australian angiosperms. Surrey admitted to me that the more that he studied aquatic plants, the more challenging he found them; thus began a fascination that would persist with him throughout the remainder of his life. That conversation is corroborated by Surrey's own words from a speech he prepared for the Aquatic Plant Management Society (APMS), which presented him with a distinguished service award in 2009 (APMS 2009):

'I started work at the Royal Botanic Gardens, Sydney as a grass taxonomist. When I was told after one year that I would also have to take on several families of the so-called 'aquatics', I squealed and complained bitterly. Fortunately my complaints fell on deaf ears. It quickly became obvious to me how much less was known about aquatic plants than the grasses. For my own convenience I started trying to organise what was known about Australian waterplants.'

His familiarity with the vegetation of saline terrestrial habitats helped to ease Surrey's transition toward the wetter spectrum of the environment, by inspiring him initially to tackle saltwater and saltmarsh plants as his first papers dealing with aquatics. In 1980, he described his very first species (Samolus eremaeus), a saltmarsh plant (Jacobs 1980), and also published a study of the seagrass genus Zostera (Jacobs \& Williams 1980). There, even 30 years ago, one already finds the logic, to which Surrey would adhere throughout his career. Essentially, he believed that the most important taxonomic issues were those that arose from a practical need to clarify a specific problem. Many of these problems revolved around identification. If he as a professional botanist could not easily identify a plant, then it was doubtful that many others could. In such instances, he would seek a sensible solution, which then could be conveyed to others.

In the case of Zostera, the problem was simply that many of the specimens found in herbaria were collected in vegetative condition. Because the keys were written to emphasise reproductive characters, many specimens were not readily identifiable. In this case, the practical need was to develop a reliable method of identification based on vegetative characteristics. The solution was to collect a large amount of fertile material, which could be identified reliably to species (27 of the Zostera specimens cited were collected by Surrey himself), and then to evaluate as many vegetative and anatomical characters as possible to determine their utility in providing a correct species determination. The resulting paper (Jacobs \& Williams 1980) is short and to the point, providing a thorough evaluation of the taxonomic utility of non-reproductive characters in Zostera. Several years later, Surrey unsuspectingly tackled another seagrass (Ruppia), which at that time was thought to be closely allied to the freshwater family Potamogetonaceae (Jacobs \& Brock 1982). That paper doubled the accepted number of Australian species from two to four and corrected the misapplication of the widely used name $R$. spiralis.

Within a year of the Zostera paper, Surrey appeared as co-author on a major treatise dealing with the waterplants of New South Wales (Sainty \& Jacobs 1981), where he combined his expertise with that of Geoff Sainty, an already well-established specialist on Australian aquatic vegetation who would remain as Surrey's friend and colleague for nearly three decades. It is no surprise that their treatment of Zostera (Sainty \& Jacobs 1981) included keys modified to accommodate the observations of the earlier papers on Zostera (Jacobs \& Williams 1980) and Ruppia (Jacobs \& Brock 1982). As a student, I remember being quite impressed by that book, which was how I first learned of Surrey as an aquatic botanist. The authors' notes in the text confirm that Surrey had 
only recently been initiated with the aquatic flora as he was described as ' ... becoming involved with waterplants in the last few years' (Sainty \& Jacobs 1981; p. 531). However, Surrey's changing heart toward aquatics clearly is evident in this publication, to which he contributed much of his 'own time and expense' (APMS 2009).

Geoff and Surrey went on to co-author numerous books and papers on aquatics, including several editions of 'Waterplants in Australia' (Sainty \& Jacobs 1987, 1988, 1994,2003), which reveal Surrey's incrementally increasing acceptance of aquatic plants. By 1988 it was acknowledged that '... Surrey has spent much of his time avoiding deep holes in swamps' (Sainty \& Jacobs 1988; p. 8). Just six years later, he is shown immersed in water up to his chest (Fig. 1.), '... looking for fruit on Pondweed and Ribbonweed ...' (Sainty \& Jacobs 1994); ultimately, he is depicted as a '... Taxonomist, specialising in waterplants for 30 years, up to his knees in a wetland.' (Sainty \& Jacobs 2003). The transformation from avoiding wet places to immersing himself in them finally had come full circle.

There is no question that Surrey's taxonomic insights were finely honed by his extensive field experience. Barre Hellquist (Professor Emeritus, Massachusetts College of Liberal Arts), a mutual colleague of Surrey and mine, recently remarked, 'I don't believe there was another person more familiar with the Australian continent than Surrey.' I agreed wholeheartedly. My first interaction with Surrey was a two-week field trip through Queensland, where he arranged to take me on a search for Zostera and other aquatics. My trip would have been nearly useless if it wasn't for Surrey. He knew exactly where to locate the plants, literally saving me months of what otherwise would have been futile searching (some sites were so remote that even GPS coordinates had to be supplemented by his experienced eye). He also knew precisely where to obtain food,

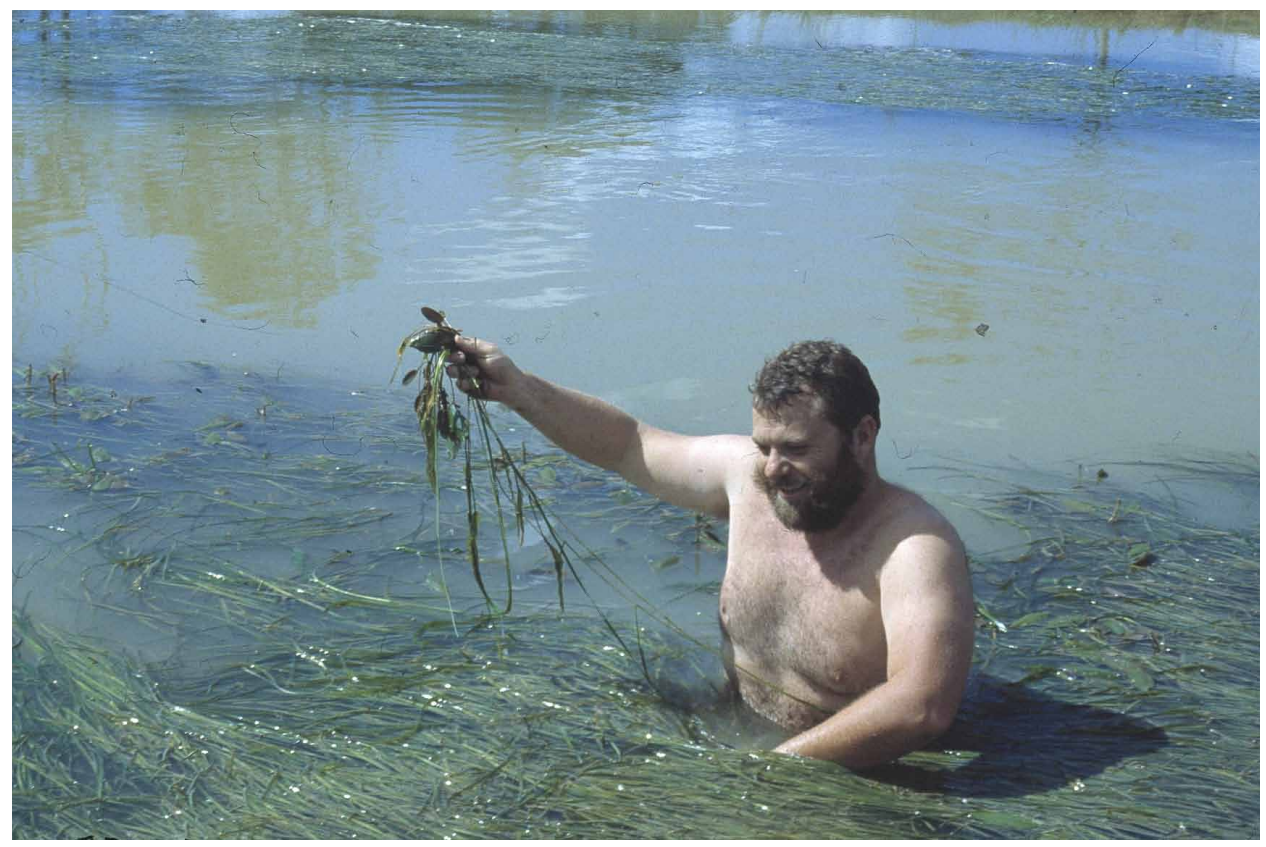

Fig. 1. Surrey Jacobs in 1981 near Bundaberg, Queensland (photo by G. Sainty). 
lodging, and gasoline (and everything else from opals to the best liqueur muscat), even in the most remote parts of the continent. To underscore the efficiency of Surrey's expert field guidance, he and I obtained enough research material in that two-week period to eventually enable us to co-author six papers on Aponogeton, Vallisneria, and Zostera (Les et al. 2002, 2005; Jacobs et al. 2006a, 2006b; Les et al. 2008; Jacobs \& Les 2009).

Surrey's perspective of field work considered both the collector and the collections equally: 'Field studies not only offer the benefit of collecting and learning about your target species, but also to learn about your colleagues, and for them to learn about you.' (APMS 2009). The early Zostera work already had alerted him to the fact that the existing study material of aquatic plant specimens was greatly inadequate and that progress in clarifying taxonomic issues could not be achieved without better and more extensive collections. Indeed, none of Surrey's taxonomic refinements of Australian aquatics would have been possible without the enhanced collection of material provided by him and his colleagues.

It was no secret that Surrey thoroughly enjoyed meeting different people from different parts of the world and interacting with them on these field excursions. Indeed, these trips provided a mutual learning experience. Friendship played a huge part in Surrey's establishment of a successful field network throughout Australia, and he once remarked, '... most people who have spent reasonable periods in the field with me have remained lifelong friends and collaborators.' (APMS 2009). Surrey's numerous contacts provided everything from lodging (for him and his field guests) to collection assistance and camaraderie. Sometimes a bottle of fine scotch would be exchanged as compensation. During the long driving hours of our trip I also learned of the local anthropology, botany, dangers (such as biting crocs, stinging trees, and 'stroppy' snakes), geology, history, music, and was reminded constantly (often with a chuckle) of how to properly pronounce Australian place names (although the different elocution of 'Barcaldine' by different Australians still confuses me).

Surrey was a cautious man and was well acquainted with the dangers associated with collecting waterplants in the Australian tropics. On one trip he was accompanied by Barre Hellquist and John Wiersema (USDA) to collect Nymphaea specimens on Cape York, where they camped a night in Lakefield National Park. Barre recounted: 'Surrey seemed a little squeamish about this site. The three of us pitched our tents. About one hour after retiring I heard a car door close. In the morning John and I found him sleeping in the vehicle. It seemed he was willing to sacrifice two Americans to the crocodiles.' (personal communication, 2009). Despite this humorous anecdote, I found Surrey to be explicit in pointing out any possible dangers associated with collecting at a particular site. He always thoroughly clarified any potential peril, but then would leave it up to each person to decide whether to heed his warnings.

In my opinion, Surrey's waterplant interests were inspired most strongly by the beautiful genus Nymphaea. One could not look around just about any room of his house without finding some type of print, photo, or other allusion to waterlilies. On the wall of his office was a needlework hanging of a water-lily with the insightful phrase, 'Sometimes I sits and thinks - sometimes I just sits'. Moreover, three of the new Nymphaea species (Jacobs 1992; Jacobs \& Hellquist 2006; Jacobs \& Hellquist 2011) were named after his daughter and grandchildren. In fairness, he did name terrestrial grass species after his son and wife; I won't comment on who got the better of that deal. 
Prior to Surrey's attention, only one native waterlily species ( $N$. gigantea) was confidently recognised in Australia, along with a bewildering array of proposed taxa, which indicated '... confusion and the need for research in Nymphaea...' (Aston 1973). Surrey first conveyed his emerging Nymphaea insights in the Water Garden Journal (Jacobs 1989), and formally described three new species and one new subspecies a few years later (Jacobs 1992; Table 1). He was especially fond of organisations such as the APMS and International Waterlily and Water Gardening Society (IWGS), which focused on the management and practical uses of aquatic plants. Surrey strongly felt that it was important to establish credibility to his research by 'extension' work, which he defined as '... the communication of science to everyday management practices' (APMS 2009). Waterlilies clearly fulfilled all of Surrey's objectives. Not only were they in desperate need of study, but any new taxonomic information also would be of practical use to gardeners and horticulturists. It is no wonder they captivated him for nearly 30 years (Fig. 2).

Surrey's water-lily studies eventually attracted the interest of Barre Hellquist, an aquatic plant and water-lily expert from the United States. Surrey related that Barre and 'his entourage' simply showed up at his small office one day, a providential visit that led to another long, collaborative friendship. Barre and Surrey spent many field seasons together, collecting water-lilies and other aquatic plants, eventually naming another six new waterlily species and five Aponogeton species (Table 1). Surrey's intensive study of Australian water-lilies, which involved countless hours collecting new specimens in the field, paid off superbly. From a confusing group with only one arguably native Australian species, a far better picture of waterlily diversity emerged, which eventually comprised an assemblage of 16 native taxa (N. gigantea, $N$. hastifolia, N. macrosperma, $N$. nouchali, $N$. pubescens, $N$. violacea and 10 newly named taxa; Table 1 ). In addition, Surrey's collaboration with other researchers produced the first phylogenetic hypothesis

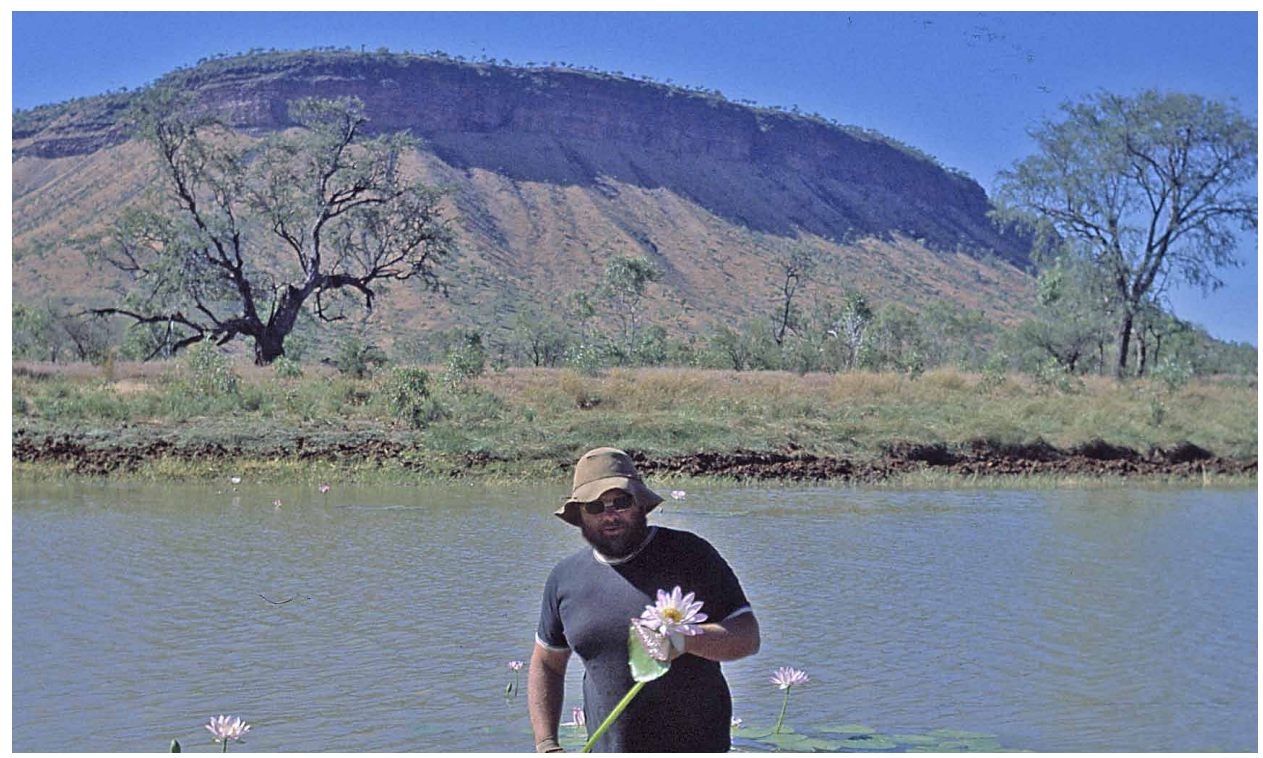

Fig. 2. Surrey Jacobs in 1982, holding a flower of Nymphaea violacea near Tableland Station, Kimberley (photo by G. Sainty). 
Table 1. Aquatic and wetland taxa authored by Surrey W. L. Jacobs.

Taxon

Alismataceae

Astonia S.W.L.Jacobs

Astonia australiensis (Aston) S.W.L.Jacobs

Aponogetonaceae

Section Flavida Les, S.W.L.Jacobs \& M.Moody

Section Viridis Les, S.W.L.Jacobs \& M.Moody

A. elongatus subsp. fluitans Hellq. \& S.W.L.Jacobs

A. cuneatus S.W.L.Jacobs

A. euryspermus Hellq. \& S.W.L.Jacobs

A. kimberleyensis Hellq. \& S.W.L.Jacobs

A. lancesmithii Hellq. \& S.W.L.Jacobs

A. proliferus Hellq. \& S.W.L.Jacobs

A. tofus S.W.L.Jacobs

A. vanbruggenii Hellq. \& S.W.L.Jacobs

Hydrocharitaceae

Ottelia ovalifolia Rich. subsp. chrysobasis S.W.L.Jacobs

Vallisneria annua S.W.L.Jacobs \& K.A.Frank

V. australis S.W.L.Jacobs \& Les

V. erecta S.W.L.Jacobs

V. rubra (A.B.Rendle) Les \& S.W.L.Jacobs

V. triptera S.W.L.Jacobs \& K.A.Frank

Nymphaeaceae

Nymphaea subgen. Confluentes S.W.L.Jacobs

Nymphaea alexii S.W.L.Jacobs \& Hellq.

N. atrans S.W.L.Jacobs

N. caerulea Savign. subsp. zanzibarensis (Casp.) S.W.L.Jacobs

N. carpentariae S.W.L.Jacobs \& Hellq.

N. elleniae S.W.L.Jacobs

N. georginae S.W.L.Jacobs \& Hellq.

N. immutabilis S.W.L.Jacobs

N. immutabilis subsp. kimberleyensis S.W.L.Jacobs

N. kimberleyensis S.W.L.Jacobs \& Hellq.

N. lukei S.W.L.Jacobs \& Hellq.

N. noeliae S.W.L.Jacobs \& Hellq.

N. vaporalis S.W.L. Jacobs \& Hellq.

Theophrastaceae

Samolus eremaeus S.W.L.Jacobs

Zosteraceae

Zostera chilensis (J.Kuo) S.W.L.Jacobs \& Les

Z. muelleri subsp. capricorni (Ascherson) S.W.L.Jacobs

Z. muelleri subsp. mucronata (Hartog) S.W.L.Jacobs

Z. muelleri subsp. novazelandica (Setchell) S.W.L.Jacobs

Z. nigricaulis (J.Kuo) S.W.L.Jacobs \& Les

Z. polychlamys (J.Kuo) S.W.L.Jacobs \& Les

\section{Reference}

Jacobs 1997

Jacobs 1997

Les et al. 2005

Les et al. 2005

Hellquist \& Jacobs 1998

Jacobs et al. $2006 \mathrm{~b}$

Hellquist \& Jacobs 1998

Hellquist \& Jacobs 1998

Hellquist \& Jacobs 1998

Hellquist \& Jacobs 1998

Jacobs et al. 2006b

Hellquist \& Jacobs 1998

Jacobs 1994b

Jacobs \& Frank 1997

Les et al. 2008

Les et al. 2008

Les et al. 2008

Jacobs \& Frank 1997

Jacobs \& Porter 2007

Jacobs \& Hellquist 2006

Jacobs 1992

Jacobs 1994 a

Jacobs \& Hellquist 2006

Jacobs 1992

Jacobs \& Hellquist 2006

Jacobs 1992

Jacobs 1992

Jacobs \& Hellquis 2011

Jacobs \& Hellquist 2011

Jacobs \& Hellquist 2011

Jacobs \& Hellquist 2011

Jacobs 1980

Jacobs \& Les 2009

Jacobs, Les \& Moody 2006a

Jacobs, Les \& Moody 2006a

Jacobs, Les \& Moody $2006 a$

Jacobs \& Les 2009

Jacobs \& Les 2009

for Australian water-lilies, which showed them to comprise an extremely complex group with reticulate relationships (Löhne et al. 2008).

The situation with Vallisneria was more circuitous. Originally I planned to work with Surrey on Zostera during my sabbatical visit to Australia in 1999-2000, but he had other thoughts. His interest in Vallisneria was first whetted by the discovery of two new species (Jacobs \& Frank 1997). Soon afterwards he wrote a popular account of the Australian 
Vallisneria species for the aquarist journal Aqua-Planta (Jacobs 1999a, 1999b), which reinforced his 'outreach' commitment to disseminate the practical applications of his taxonomic research. So, soon after Surrey first picked me up to begin our Zostera field work, he stopped to point out a stand of Vallisneria, indicating that the Australian botanists had been calling it $V$. americana. One look at the distinctive specimens and I replied that it certainly was not the same plant that we had in North America by that name. His response was simple, 'So, how do we work it out?'

Surrey quickly encouraged me to work with him on the Australian vallisnerias, which were giving him nightmares. Like many Australian aquatics, the genus was a taxonomic mess. Previous treatments had recognised only two or three species in the country, and had virtually ignored the caulescent taxa (most species are rosulate). Surrey's field work had uncovered V. triptera (Jacobs \& Frank 1997), a caulescent species so conspicuous that it is hard to believe it could have gone unnoticed for so long. This and the previously named caulescent $V$. caulescens were quite distinct from the caulescent Maidenia, an Australian endemic believed to represent the closest relative of the genus, but arguably belonging to it (Aston 1973). Interestingly, that same year his keen eye also discovered a new alismatid genus Astonia, which he named after the Australian aquatic plant specialist Helen Aston (Jacobs 1997a).

However, the 'stickiest' Vallisneria problems involved the rosulate taxa. Hartog (1957) had assigned all rosulate Australian vallisnerias to the name $V$. gigantea $[=V$. nana]. Aston (1973) followed a similar scheme, but replaced V. gigantea with V. spiralis, applying the latter as what she believed to represent the appropriate taxon name. Aston (1973) also recognised a second rosulate species, $V$. gracilis, which had been distinguished by its very fine foliage. Jacobs and Frank (1997) began to sort out these taxa, ultimately deciding that the more tropical segregate of $V$. spiralis s. lat. should be recognised as distinct (as $V$. nana) from the temperate segregate, which they called $V$. americana in deference to the latest global taxonomic revision by Lowden (1982). Surrey had reached an impasse trying to use morphological characters to straighten out this group any further. When he met me, he hoped that my expertise with molecular (DNA sequence) data could help him to resolve this problem more satisfactorily.

Surrey was not one to dogmatically embrace molecular systematic approaches to taxonomic problems and certainly had no desire to conduct such research on his own as an alternative to his beloved fieldwork. Yet, he quickly recognised the utility of such approaches once it became clear that they often could help clarify questions, which otherwise remained intractable, and already had co-authored a molecular paper on grasses (Hsiao et al. 1998). Surrey viewed molecular data in the proper context, as a means of providing additional data (but not the only data) to bear on a taxonomic problem. He always remained a bit suspicious of molecular results, especially if they indicated some unusual association. That's one reason why we got along so well; we had to convince each other of the interpretation of all the data, which ended up providing some decent solutions.

We collected a number of additional Vallisneria specimens on our trip (preserving material for DNA analysis in all cases), and these were later supplemented by Surrey's own collections, including DNA samples. I introduced him to the use of liquid CTAB preservative, which could fix field collections of plants for DNA analysis without requiring refrigeration, a luxury which represented a near impossibility on most remote field excursions. Surrey already had adopted the habit of collecting alcohol-preserved 
specimens (especially for reproductive structures) in addition to the standard dried herbarium specimens, so adding some extra plant material to a vial of CTAB for DNA work seemed simple enough and he eventually included the approach routinely in his collecting protocol.

The Vallisneria work took on a life of its own. By the time we had finished, this study of Australian taxa included nearly every recognised species on earth, providing for a worldwide treatment of the genus. By using a combined morphological/molecular approach, we eventually did clarify the Australian Vallisneria taxa satisfactorily. Not only was the 'tropical segregate' of V. spiralis s. lat. distinct from V. nana, it also was distinct from both $V$. americana and $V$. spiralis, resulting in the new species $V$. australis (Les et al. 2008). Also, we had strong evidence to merge the monotypic genus Maidenia with Vallisneria, where it associated with the other caulescent taxa. If Surrey had not worked on the Australian vallisnerias, they would have remained a genus of 3-5 species worldwide; as a consequence of his persistence, we now have 15, with eight of them in Australia (Les et al. 2008).

It is an understatement to say that Surrey was efficient in the field and he routinely would set off with a list of plants that others had requested he collect, realising that it is best to accomplish as much as possible when one is hundreds or even thousands of kilometers from home. This logic was aptly applied on our field trip, which was designed to collect Zostera, but somehow also managed to accumulate reasonable numbers of Vallisneria and Aponogeton specimens. Surrey already had been working on the aponogetons with Barre Hellquist, who joined him in naming five new species (Table 1), a number already eclipsing the four native species accepted before they began their project. Like our Vallisneria undertaking, my job was to seek corroboration of the new taxonomic scheme necessitated by the recent species discoveries by analysing molecular data obtained from newly collected field material. Aponogeton turned out to be a tangled array of hybrids and polyploids and took quite an effort to sort out. When all was said and done, we found there to be two independent origins of Australian aponogetons, and also indicated the possible existence of several additional undescribed 'cryptic' species (Les et al. 2005). Further work on Surrey's part eventually resulted in the publication of two more species names (Jacobs et al. 2006b), raising the total count of native Australian aponogetons to 11, more than twice the original number.

These comments bring me finally back to Zostera. Unlike Aponogeton, Nymphaea and Vallisneria, the Zosteraceae work actually reduced the number of recognised native Australian species and genera. The fairly extensive survey of Zostera populations from our own field work and material sent to us by others, enabled us to argue that there were only two clearly defensible species, $Z$. muelleri (incl. Z. capricornii, Z. mucronata, $Z$. novazelandica) and $Z$. tasmanica, which originally had been segregated as the genus Heterozostera, but was found to nest within Zostera (Les et al., 2002). Surrey had no problem merging Heterozostera, but he was somewhat reluctant about sinking the three Australian Zostera species into Z. muelleri, even though he fully agreed that all of the evidence supported that conclusion. However, Surrey's practical side eventually got the better of him and he decided to establish new combinations that would at least allow one to recognise the former species as subspecies (mainly to preserve 'valuable field information'), despite the fact that there was a '... considerable (?uncomfortable) degree of character overlap between them.' (Jacobs et al. 2006a). A few years later Kuo (2005) revised the genus Heterozostera (not accepting its merger with Zostera) in which he named three new species. To alleviate any potential taxonomic problems, Surrey 
arranged new combinations for those new species so that if they were to be recognised, then at least they could be recognised as species of Zostera (Jacobs \& Les 2009). It was our last paper together, and marked a collaboration that first began with Zostera and now, ironically, ended with Zostera.

Surrey's other contributions to aquatic plants are manifold and too numerous to discuss adequately in the present paper. They span diverse topics ranging from a biogeographical analysis, which indicated that the aquatic Australian species mainly represent distinct tropical and temperate assemblages (Jacobs \& Wilson 1996), to the spread of aquatic species in constructed wetlands (Jacobs et al. 1995b) and accounts on the invasive species Elodea (Bowmer et al. 1995) and Ludwigia (Jacobs et al. 1993, 1995a). A comprehensive listing of all his contributions on aquatic plants is included in the References section, where any contribution not specifically cited in the text is marked by an asterisk.

How does one evaluate the impact of Surrey Jacobs' contributions to aquatic plant research? Time will tell whether all of the new aquatic taxa named by Surrey will persist to become integrated permanently into the literature dealing with the Australian flora. Yet, there is no doubt that at least a significant number of his new taxa will withstand taxonomic scrutiny by future researchers. Already, several of the new species have been incorporated into treatments on the aquatic floras of the Northern Territory (Cowie et al. 2000) and Queensland (Stephens \& Dowling 2002). His numerous publications and fact-laden books also have enhanced the understanding of many Australian aquatic plants to a level not achieved previously. Moreover, his extensive collections of aquatic plants represent a substantial legacy, which will provide an important resource to students of Australian biodiversity long into the future.

However, his research record notwithstanding, one cannot forget that Surrey's mentorship of young researchers and students interested in aquatic plants also represented one of his most important achievements. His supervision of graduate students at his own institution included Joanne Ling (Biological assessment of wetlands) and Sabine Papasotiriou (systematics of Australian Potamogeton). He also assumed an advisory role for students coming to Australia from other institutions to conduct fieldwork. These included Yu Ito (Ruppia) from the University of Tokyo, Japan, and several of my own Ph.D. students from the University of Connecticut. In particular, Surrey spent a considerable amount of time providing extensive field assistance to students such as Lori Benoit (Hydrilla), Michael Moody (Haloragaceae), Nic Tippery (Menyanthaceae), and Amy Weiss (Cabomba). Their careers have benefitted tremendously from the interaction. Nic Tippery nicely summarised the experience: 'I can't imagine how impoverished my life or academic career would be had I not worked with Surrey in Australia' (personal communication, 2009). I believe that statement aptly sums it up for all of us who were fortunate enough to know and work with this remarkable scientist, colleague and friend. 


\section{Acknowledgments}

Information for this article was based partly on field work to Australia funded by CSIRO, the Fulbright Academy and the National Science Foundation (DEB-0309123). Photographs were generously provided by Geoff Sainty. I thank Karen Wilson for giving me the opportunity to contribute this article as an invited contributor to this appropriate issue dedicated to Surrey.

\section{References (* not cited in text)}

APMS (2009) Transcript of Aquatic Plant Management Society Distinguished Service award acceptance speech written by SWL Jacobs [delivered by DH Les, July 15, 2009].

Anderson DJ, Jacobs SWL \& Malik AR (1967) Studies on structure in plant communities VI. The significance of pattern evaluation in some Australian dry-land vegetation types. Australian Journal of Botany 15: 315-322.

Aston HI (1973) Aquatic plants of Australia. Melbourne University Press, Melbourne.

*Aston HI \& Jacobs SWL (1980) Hydrocleys nymphoides (Butomaceae) in Australia. Muelleria 4: 285-293.

${ }^{*}$ Benson J \& Jacobs SWL (1994) Plant communities of the Monaro lakes. Cunninghamia 3: 651-676.

${ }^{\star}$ Booth CA, Church AG, Erskine WD, Hoese DF, Jacobs SWL \& Marr AJ (1998) Experimental environmental flows and related ecosystem monitoring and research of the Coxs River below Lyell Dam. Report for Department of Land and Water Conservation. Centre for Integrated Catchment Management. University of Western Sydney (Hawkesbury), Richmond.

Bowmer KH, Jacobs SWL \& Sainty GR (1995) Identification, biology and management of Elodea canadensis, Hydrocharitaceae. Journal of Aquatic Plant Management 33: 13-19.

Carolin RC, Jacobs SWL \& Vesk M (1975) Leaf structure in the Chenopodiaceae. Botanische Jahrbücher für Systematik 95: 226-255.

Carolin RC, Jacobs SWL \& Vesk M (1978) Kranz cells and mesophyll in the Chenopodiales. 1978. Australian Journal of Botany 26: 683-698.

Chapman EA \& Jacobs SWL (1980) Photosynthetic responses of some arid zone plants. Studies in the Arid Zone 4: 41-53.

Cowie ID, Short PS \& Osterkamp Madsen M (2000) Floodplain flora - A flora of the coastal floodplains of the Northern Territory, Australia. Flora of Australia Supplementary Series No. 10. Australian Biological Resources Study, Canberra, Australia.

${ }^{\star}$ Green J, Reichelt-Brushett A \& Jacobs SWL (2009a) Re-establishing a saltmarsh vegetation structure in a changing climate. Ecological Management \& Restoration 10: 20-30.

${ }^{*}$ Green J, Reichelt-Brushett A \& Jacobs SWL (2009b) Investigating gastropod habitat associations in saltmarsh. Wetlands 25: 25-37.

Hartog C den (1957) Hydrocharitaceae. Pp. 381-413 in Steenis CGGJ (ed.) Flora Malesiana series 1, vol. 5. van Noordhoff-Kolff N.V., The Netherlands.

Hellquist CB \& Jacobs SWL (1998) Aponogetonaceae of Australia with descriptions of six new taxa. Telopea 8: 7-19.

${ }^{\star}$ Hellquist CB \& Jacobs SWL (submitted) Aponogetonaceae. Flora of Australia.

Hsiao C, Jacobs SWL, Barker NP \& Chatterton NJ (1998) A molecular phylogeny of the subfamily Arundinoideae (Poaceae) based on sequences of rDNA (ITS). Australian Systematic Botany 11: 41-52.

Jacobs SWL (1974) Ecological studies on the genera Triodia R.Br. and Plectrachne Henr. in Australia. Ph.D. thesis, University of Sydney.

Jacobs SWL (1980) A new species of Samolus (Primulaceae). Journal of the Adelaide Botanic Gardens 2: 187-189.

*Jacobs SWL (1983a) The families Aizoaceae, Nymphaeaceae, Cabombaceae and Nelumbonaceae. Pp. 49-53 \& 72-73 in Morley B \& Toelken H (eds) Flowering plants in Australia. Reeds, Sydney. 
${ }^{\star}$ Jacobs SWL (1983b) Wetlands Vegetation. Pp. 14-19 in C. Haigh (ed.) Parks and Wildlife, Wetlands Issue. National Parks and Wildlife Service, Sydney.

${ }^{\star} J a c o b s$ SWL (1985) Adaptations in water plants. Pp 7-35 in Johnstone J (ed.) Plant Adaptations. Education Unit, Royal Botanic Gardens, Sydney.

*Jacobs SWL (1988) Progress in Australian aquatic plant taxonomy. Pp. 179-191 in Gilligan B Maddock M \& McDonald K (eds) Hunter Wetland Trust Symposium.

Jacobs SWL (1989) Nymphaea in Australia. Water Garden Journal 5: 14-18.

*Jacobs SWL (1990) The families Cabombaceae, Ceratophyllaceae, Nymphaeaceae, Papaveraceae and Elatinaceae. Pp. 148-151 in Harden GJ (ed.) Flora of New South Wales, vol. 1. New South Wales University Press, Sydney.

Jacobs SWL (1992) New species, lectotypes and synonyms of Australasian Nymphaea (Nymphaeaceae). Telopea 4: 635-641.

*Jacobs SWL (1993a) Consider the lilies. Wildlife Australia 30(1): 7-9.

${ }^{\star}$ Jacobs SWL (1993b) Must be the season of the Wet. Wildlife Australia 30(1): 14-15.

*Jacobs SWL (1993c) The families Aponogetonaceae, Hydrocharitaceae, Alismataceae, Juncaginaceae, Lilaeaceae, Najadaceae, Potamogetonaceae (with S. Papassotiriou), Zosteraceae, Posidoniaceae, Cymodoceaceae and Zannichelliaceae. Pp. 11-31 in Harden GJ (ed.) Flora of New South Wales, vol. 4. New South Wales University Press, Sydney.

Jacobs SWL (1994a) Further notes on Nymphaea in Australasia. Telopea 5: 703-706.

*Jacobs SWL (1994b) Ottelia ovalifolia subsp. chrysobasis (Hydrocharitaceae), a new Australian subspecies. Telopea 5: 789-790.

*Jacobs SWL (1994c) Aquatic plants, ferns, grasses and tropical weeds of Cape York Peninsula. Pp. 43-49 in Cape York Peninsula Scientific Expedition 1992 vol. 2. The Royal Geographical Society of Queensland, Brisbane.

*Jacobs SWL (1996) Introduction of weeds to the aquatic environment. Pp 1-17 in Weed management in a wetland environment. Proceedings of The Weed Society of New South Wales Conference, 1996.

Jacobs SWL (1997a) Astonia (Alismataceae), a new genus for Australia. Telopea 7: 139-141.

${ }^{\star} J a c o b s$ SWL (1997b) Wetland plant communities. National Parks Journal 41 (6): 6-7.

*Jacobs SWL (1998) Monitoring and assessing wetlands using macrophytes. Pp. 34-37 in Brady A (ed.) Proceedings of the Department of Land and Water Conservation Wetlands Conference and Workshop, 28-30 April, 1997, Myall Lakes. Department of Land and Water Conservation, Parramatta.

Jacobs SWL (1999a) Die gattung Vallisnéria L. (Hydrocharitaceae) in Australia (Teil 1) (Übersetzung Josef Bognor, München). Aqua-Planta 3-99: 95-101.

Jacobs SWL (1999b) Die gattung Vallisnéria L. (Hydrocharitaceae) in Australia (Teil 2) (Übersetzung Josef Bognor, München). Aqua-Planta 4-99: 151-156.

*Jacobs SWL (1999c) Terrestrial wetlands and waterplants. Pp. 403-435 in Orchard AE \& Thompson HS (eds) Flora of Australia vol. 1, ed 2. CSIRO Publishing and the Australian Biological Resources Study, Canberra.

* Jacobs SWL (2000) Alien invaders. Water Garden Journal 15: 32-35.

*Jacobs SWL (2001) Selecting, growing and establishing wetland plants. Workshop Proceedings, paper 9, Constructed Wetlands for Stormwater Management. Stormwater Industry Association, NSW, Sydney.

*Jacobs SWL (2004) Lectotypification of Alisma oligococcum F. Muell. (Alismataceae). Telopea 10: 840.

*Jacobs SWL (2007a) Zwei neue Aponogeton-arten (Aponogetonaceae) und un schlüssel für die australischen arten. Aqua Planta 1-2007: 4-11.

${ }^{\star}$ Jacobs SWL (2007b) Nymphaea subg. Confluentes. P. 458 in Wilson AJG (ed.) Flora of Australia, vol. 2. CSIRO, Canberra.

Jacobs SWL \& Brock MA (1982) A revision of the genus Ruppia (Potamogetonaceae) in Australia. Aquatic Botany 14: 325-337. 
${ }^{*}$ Jacobs SWL \& Brock MA (1993) Wetlands of Australia: southern (temperate) Australia. Pp. 244-304 in Whigham DF, Dykyjov D \& Hejny S (eds) Wetlands of the world: inventory, ecology and management, vol. 1. Kluwer Academic Publishers, Dordrecht.

${ }^{\star}$ Jacobs SWL \& Brock MA (submitted) Ruppiaceae. Flora of Australia.

Jacobs SWL \& Frank KA (1997) Notes on Vallisneria (Hydrocharitaceae) in Australia, with descriptions of two new species. Telopea 7: 111-118.

${ }^{\star}$ Jacobs SWL \& Frank KA (submitted) Alismataceae. Flora of Australia.

${ }^{\star}$ Jacobs SWL \& Frank KA (submitted) Hydrocharitaceae. Flora of Australia.

${ }^{\star}$ Jacobs SWL \& Frank KA (submitted) Limnocharitaceae. Flora of Australia.

${ }^{\star}$ Jacobs SWL \& Frank KA (submitted) Najadaceae. Flora of Australia.

${ }^{\star}$ Jacobs SWL \& Frank KA (submitted) Zannichelliaceae. Flora of Australia.

${ }^{*}$ Jacobs SWL \& Hellquist CB (2000a) Aponogetonaceae of Australia. The Water Garden Journal 15: $27-31$.

*Jacobs SWL \& Hellquist CB (2000b) Die Aponogeton-arten (Aponogetonaceae) Australiens Teil 1. Aqua-Planta 2000(4): 142-147.

${ }^{*}$ Jacobs SWL \& Hellquist CB (2001a) Die Aponogeton-arten (Aponogetonaceae) Australiens Teil 2. Aqua-Planta 2001(1): 14-21.

${ }^{*} J a c o b s$ SWL \& Hellquist CB (2001b) Die Aponogeton-arten (Aponogetonaceae) Australiens Teil 3. Aqua-Planta 2001(3): 120-126.

Jacobs SWL \& Hellquist CB (2006) Three new species of Nymphaea (Nymphaeaceae) in Australia. Telopea 11: 155-160.

Jacobs SWL \& Hellquist CB (2011) New species, possible hybrids and intergrades in Australian Nymphaea (Nymphaeaceae) with a key to all species. Telopea 13: 233-243.

Jacobs SWL \& Les DH (2009) New combinations in Zostera (Zosteraceae). Telopea 12: 419-423. *Jacobs SWL \& Porter CL (2007) Nymphaeaceae. Pages 259-275 in Flora of Australia. Vol 2. Winteraceae to Plantaginaceae. CSIRO, Canberra.

* Jacobs SWL \& Sainty GR (1987) Water weeds into the third century. Pp. 148-151 in Lemerle D \& Leys AR (eds) Proceedings of the 8th Australian Weeds Conference. Sydney.

Jacobs SWL \& Williams A (1980) Notes on the genus Zostera s. lat. in New South Wales. Telopea 1: 451-455.

Jacobs SWL \& Wilson KL (1996) Biogeographical analysis of the freshwater plants of Australasia. Australian Systematic Botany 9: 169-183.

Jacobs SWL, Les DH \& Moody ML (2006a) New combinations in Australasian Zostera (Zosteraceae). Telopea 11: 127-128.

Jacobs SWL, Les DH, Moody ML \& Hellquist CB (2006b) Two new species of Aponogeton (Aponogetonaceae) and a key to species from Australia. Telopea 11: 129-134.

*Jacobs SWL, Lindsay G, Sainty G \& Skelton N (1997) Wetland and saltmarsh assessment: vegetation based protocols and database. Pp. 152-155 in Riley S, Erskine W \& Shrestha $\mathrm{S}$ (eds) Proceedings of the Conference on Science and Technology in the Environmental Management of the Hawkesbury-Nepean Catchment. Conference Papers No. 14, Australia National Conference Publication NCP 97/01. Institution of Engineers, Geographical Society of New South Wales, Chester Hill, New South Wales.

Jacobs SWL, Perrett F, Brock M, Bowmer KH, McCorkelle G, Rawling J, Stricker J \& Sainty GR (1993) Ludwigia peruviana - description and biology. Pp. 225-228 in Swarbrick JT, Henderson CWL, Jettner RJ, Streit L \& Walker SR (eds) Proceedings 10th Australian and 14th Asian-Pacific Weed Conference, vol. 1. The Weed Society of Queensland, Brisbane.

Jacobs SWL, Perrett F, Sainty GR, Bowmer KH \& Jacobs BJ (1995a) Ludwigia peruviana (Onagraceae) in the Botany wetlands near Sydney, Australia. Australian Journal of Marine and Freshwater Research 45: 1481-1490.

Jacobs SWL, Sainty GR, Adcock PW \& Hunter GJ (1995b) Establishment and spread of waterplant species in a constructed wetland at Blacktown, N.S.W., Australia. Pp. 193-202 in Proceedings of National Conference on Wetlands for Water Quality Control. James Cook University, Townsville. 
Kuo J (2005) A revision of the genus Heterozostera (Zosteraceae). Aquatic Botany 81: 97-140.

Les DH, Jacobs SWL, Tippery NP, Chen L, Moody ML \& Wilstermann M (2008) Systematics of Vallisneria L. (Hydrocharitaceae Juss.). Systematic Botany 33: 49-65.

Les DH, Moody ML \& Jacobs SWL (2005) Phylogeny and systematics of Aponogeton (Aponogetonaceae): the Australian species. Systematic Botany 30: 503-519.

Les DH, Moody ML, Jacobs SWL \& Bayer RJ (2002) Systematics of seagrasses (Zosteraceae) in Australia and New Zealand. Systematic Botany 27: 468-484.

${ }^{\star}$ Ling JE \& Jacobs SWL (2003) Biological assessment of wetlands: testing techniques - preliminary results. Wetlands 21: 36-55.

Löhne C, Borsch T, Jacobs SWL, Hellquist CB \& Wiersma J (2008) Nuclear and plastid DNA sequences reveal complex evolutionary patterns in Australian water-lilies (Nymphaea subgenus Anecphya, Nymphaeaceae). Australian Systematic Botany 21: 229-250.

Lowden RM (1982) An approach to the taxonomy of Vallisneria L. (Hydrocharitaceae). Aquatic Botany 13: 269-298.

${ }^{\star}$ Papasotiriou S, Jacobs SWL \& Hellquist CB (submitted) Potamogetonaceae. Flora of Australia.

Sainty GR \& Jacobs SWL (1981) Waterplants of New South Wales. Water Resources Commission, New South Wales.

Sainty GR \& Jacobs SWL (1987) Waterplants in Australia. Sainty \& Associates, Darlinghurst, Australia.

Sainty GR \& Jacobs SWL (1988) Waterplants in Australia. $2^{\text {nd }}$ edition. Sainty \& Associates, Darlinghurst, Australia.

* Sainty GR \& Jacobs SWL (1991) Waterplants. Pp. 265-273 in Mackay N \& Eastburn D (eds) The Murray. Murray Darling Basin Commission, Canberra, Australia.

Sainty GR \& Jacobs SWL (1994) Waterplants in Australia. $3^{\text {rd }}$ edition. Sainty \& Associates, Darlinghurst, Australia.

*Sainty GR \& Jacobs SWL (1997a) Hawkesbury-Nepean saltmarsh assessment. HawkesburyNepean Catchment Management Trust. 20 pp.

*Sainty GR \& Jacobs SWL (1997b) Hawkesbury-Nepean wetland assessment. HawkesburyNepean Catchment Management Trust. 24 pp.

Sainty GR \& Jacobs SWL (2003) Waterplants in Australia. $4^{\text {th }}$ edition. Sainty \& Associates Pty, Potts Point, Australia.

Stephens KM \& Dowling RM (2002) Wetland plants of Queensland. A field guide. CSIRO Publishing, Collingwood, Victoria, Australia.

*Tippery NP, Les DH, Padgett DJ \& Jacobs SWL (2008) Generic circumscription in Menyanthaceae: a phylogenetic evaluation. Systematic Botany 33: 598-612.

*Wilson KL \& Jacobs SWL (1998) Gramineae, Casuarinaceae, Cyperaceae, Juncaceae and waterplants. Pp. 13-24 in Driessen MM, Comfort MD, Jackson J, Balmer J, Richardson AMM \& McQuillan PB (eds) Wilderness Ecosystems Baseline Studies (WEBS): Pelion PlainsMt Ossa. Wildlife Report 98/2. Tasmanian Parks and Wildlife Service, Hobart. 